\title{
Highly efficient degradation of organic pollutants using a microbially-synthesized nanocatalyst
}

DOI:

10.1016/j.ibiod.2016.12.008

Document Version

Accepted author manuscript

Link to publication record in Manchester Research Explorer

\section{Citation for published version (APA):}

Watts, M. P., Cutting, R., Joshi, N., Coker, V., Mosberger, A., Zou, B., Davies, C., van Dongen, B. E., Hofstetter, T., \& Lloyd, J. (2017). Highly efficient degradation of organic pollutants using a microbially-synthesized nanocatalyst. International Biodeterioration and Biodegradation, 119. https://doi.org/10.1016/j.ibiod.2016.12.008

\section{Published in:}

International Biodeterioration and Biodegradation

\section{Citing this paper}

Please note that where the full-text provided on Manchester Research Explorer is the Author Accepted Manuscript or Proof version this may differ from the final Published version. If citing, it is advised that you check and use the publisher's definitive version.

\section{General rights}

Copyright and moral rights for the publications made accessible in the Research Explorer are retained by the authors and/or other copyright owners and it is a condition of accessing publications that users recognise and abide by the legal requirements associated with these rights.

\section{Takedown policy}

If you believe that this document breaches copyright please refer to the University of Manchester's Takedown Procedures [http://man.ac.uk/04Y6Bo] or contact uml.scholarlycommunications@manchester.ac.uk providing relevant details, so we can investigate your claim.

\section{OPEN ACCESS}


Highly efficient degradation of organic pollutants using a microbially-synthesized nanocatalyst

3 Mathew P. Watts ${ }^{1 \mathrm{a}^{*}}$, Richard S. Cutting ${ }^{1^{*}}$, Nimisha Joshi ${ }^{1}$, Victoria S. Coker ${ }^{1}$, Apalona Mosberger ${ }^{2}$,

4 Boyuan Zhou ${ }^{1}$, Catherine M. Davies ${ }^{1}$, Bart E. van Dongen ${ }^{1}$, Thomas Hoffstetter ${ }^{2}$ \& Jonathan R. Lloyd ${ }^{1}$

$5{ }^{1}$ School of Earth, Atmospheric and Environmental Sciences and Williamson Research Centre for

6 Molecular Environmental Science, The University of Manchester, Manchester, M13 9PL, U.K.

$7 \quad{ }^{2}$ ETH Zürich, Inst. F. Biogeochemie u. Schadstoffdynamik, CHN G48 Universitätstrasse 16, 8092 Zürich,

8 Switzerland

$9{ }^{\text {a }}$ Current address: School of Earth Sciences, University of Melbourne, Victoria, 3010, Australia.

10 * mathew.watts@unimelb.edu.au

\section{Abstract}

13 Magnetite is a common subsurface mineral, formed biogenically in anaerobic environments. Containing

$14 \mathrm{Fe}(\mathrm{II})$, it is reactive towards a variety of common redox sensitive subsurface contaminants. To extend the reactivity of biomagnetite it is possible to add a coating of $\operatorname{Pd}(0)$ nanostructures, which is capable of

16 sustained catalytic reactivity. Here we assess the reactivity of biogenic nano-magnetite $(\mathrm{BnM})$, formed by

17 the reduction of $\mathrm{Fe}$ (III) oxyhydroxide by Geobacter sulfurreducens, to the model organic compounds nitrobenzene $\left(\mathrm{ArNO}_{2}\right)$ and tetrachloroethylene (PCE), and compare its performance to biomagnetite

19 functionalized with $\mathrm{Pd}(0)(\mathrm{Pd}-\mathrm{BnM})$. The $\mathrm{BnM}$ and the $\mathrm{Pd}-\mathrm{BnM}$ were both found to be highly reactive 20 towards $\mathrm{ArNO}_{2}$, quantitatively transforming it to the reduced product aniline $\left(\mathrm{ArNH}_{2}\right)$. When applied to 21 tetrachloroethylene (PCE), the BnM was found to be poorly reactive, while the Pd-BnM rapidly 22 dechlorinated the PCE to the benign product, ethane, at rates comparable to synthetic nano-scale 23 catalysts. The biological synthesis route proposed is highly scalable and offers a green, environmentally benign route for the production of highly reactive nanoparticles for environmental clean-up. 


\section{Introduction}

The mixed-valent iron mineral magnetite $\left(\mathrm{Fe}(\mathrm{II}) \mathrm{Fe}(\mathrm{III})_{2} \mathrm{O}_{4}\right)$ is widespread in the natural environment (Cornell and Schwertmann, 2003), formed via a diverse range of biotic and abiotic processes, including the bioreduction of poorly crystalline Fe(III) phases by dissimilatory iron reducing bacteria (Cutting et al., 2009; Lovley et al., 1987), the abiotic oxidation of ferrous or zero valent iron (ZVI) (Gu et al., 1999; Olowe et al., 1989) and the bio-oxidation of Fe(II) coupled to denitrification (Kappler and Straub, 2005) . Early studies noted that in the absence of aqueous and sorbed $\mathrm{Fe}(\mathrm{II})$ species, magnetite is relatively unreactive towards nitroaromatic and chlorinated compounds over timescales of hours (Elsner et al., 2004; Klausen et al., 1995). Other studies, however, have demonstrated the ability of both synthetic and biogenic magnetite to reduce a range of environmentally relevant contaminants such as trichloroethylene (Lee and Batchelor, 2002), carbon tetrachloride (Danielsen and Hayes, 2004) , nitrobenzene (Gorski and Scherer, 2009), nitramine explosives such as hexahydro-1,3,5-trinitro-1,3,5-triazine (RDX) (Gregory et al., 2004), Hg(II) (Wiatrowski et al., 2009), Cr(VI) (Cutting et al., 2010) , U(VI) (Missana et al., 2003) and Tc(VII) (Lloyd et al., 2000; McBeth et al., 2011).

Ultimately the reactivity of magnetite (or other solid state reductants) appears to be governed by their ability to store (capacitance) and donate electrons from $\mathrm{Fe}(\mathrm{II})$, with $\mathrm{Fe}(\mathrm{II}) / \mathrm{Fe}(\mathrm{III})$ stoichiometry noted to have a profound control on reactivity (Gorski et al., 2010; Latta et al., 2012). In an attempt to overcome the limitation of a finite capacitance inherent to $\mathrm{Fe}$ (II)-baring magnetite particles, composite catalysts have been fabricated by supporting nano-scale metallic palladium $(\operatorname{Pd}(0))$ clusters on the surfaces of biogenic magnetite nanoparticles (Coker et al., 2010; Crean et al., 2012). These nanoparticles, synthesized using an Fe(III)-reducing bacterium, were functionalized with Pd through a one-step reduction method (Coker et al., 2010). The resulting particles consisted of a biogenic magnetite (BnM) carrier ( 20 nm diameter) hosting metallic Pd particles ( $5 \mathrm{~nm})$ on its surface (Pd-BnM). When supplied with a suitable electron donor, typically $\mathrm{H}_{2}$ gas, $\mathrm{Pd}(0)$ is able to dissociate and absorb reactive $\mathrm{H} \bullet$ in to its bulk structure, available for reaction (Conrad et al., 1974; Tierney et al., 2009; Yamauchi et al., 2008). The ability to supply the reaction with fresh electron donor improves the reduction potential and longevity of particle reactivity, in comparison to the finite $\mathrm{Fe}(\mathrm{II})$ of magnetite. 
52 A number of studies employing $\mathrm{Pd}(0)$ catalysts in various forms have confirmed their exceptional reactivity against a variety of pollutants (Chaplin et al., 2012). These $\mathrm{Pd}(0)$ particles have been deployed in a number of different forms, including as native $\mathrm{Pd}(0)$ particles, and more commonly on the surface of

$\mathrm{C}_{6} \mathrm{H}_{5} \mathrm{NO}_{2}+2 \mathrm{e}^{-}+2 \mathrm{H}^{+} \rightarrow \mathrm{C}_{6} \mathrm{H}_{5} \mathrm{NO}+\mathrm{H}_{2} \mathrm{O}$

(eq. 1).

$\mathrm{C}_{6} \mathrm{H}_{5} \mathrm{NO}+2 \mathrm{e}^{-}+2 \mathrm{H}^{+} \rightarrow \mathrm{C}_{6} \mathrm{H}_{5} \mathrm{NHOH}$ (eq. 2)

$\mathrm{C}_{6} \mathrm{H}_{5} \mathrm{NHOH}+2 \mathrm{e}^{-}+2 \mathrm{H}^{+} \rightarrow \mathrm{C}_{6} \mathrm{H}_{5} \mathrm{NH}_{2}+\mathrm{H}_{2} \mathrm{O}$

(eq. 3) 
80 To further compare the reactivity of the un-functionalized Fe(II) mediated reductant, BnM, compared to

81 the catalytic, $\mathrm{Pd}-\mathrm{BnM}$, they were both also tested towards dechlorination of the relatively more recalcitrant contaminant PCE. PCE is dechlorinated via a series of potential intermediate compounds,

83 via the idealized reactions:

84

85

86

87

88

89

90

91

92

93
$\mathrm{C}_{2} \mathrm{Cl}_{4}+2 \mathrm{H}^{+}+2 \mathrm{e}^{-} \rightarrow \mathrm{C}_{2} \mathrm{HCl}_{3}+\mathrm{HCl}$

$\mathrm{C}_{2} \mathrm{HCl}_{3}+2 \mathrm{H}^{+}+2 \mathrm{e}^{-} \rightarrow \mathrm{C}_{2} \mathrm{H}_{2} \mathrm{Cl}_{2}+\mathrm{HCl}$

$\mathrm{C}_{2} \mathrm{H}_{2} \mathrm{Cl}_{2}+2 \mathrm{H}^{+}+2 \mathrm{e}^{-} \rightarrow \mathrm{C}_{2} \mathrm{H}_{3} \mathrm{Cl}+\mathrm{HCl}$

$\mathrm{C}_{2} \mathrm{H}_{3} \mathrm{Cl}+2 \mathrm{H}^{+}+2 \mathrm{e}^{-} \rightarrow \mathrm{C}_{2} \mathrm{H}_{4}+\mathrm{HCl}$

8 The assessment of the reactivity of the particles towards PCE includes a detailed assessment of the rates and end points of degradation catalyzed by $\mathrm{BnM}$ and $\mathrm{Pd}-\mathrm{BnM}$, and a critical comparison of performance with a range of synthetic analogues.

\section{Experimental section}

\subsection{Chemicals}

All chemicals used in this study were of analytical grade or purer, unless otherwise stated, and used as received without further purification prior to use. All water used in the experiments was of a minimum 18.2 $\mathrm{M} \Omega$ quality.

\subsection{Biogenic magnetite synthesis}

BnM was prepared from a starting Fe(III) phase of 2-line ferrihydrite, prepared by alkaline hydrolysis,

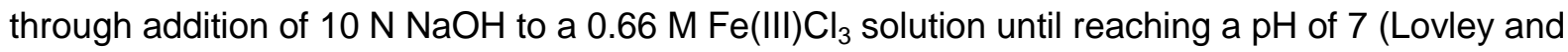
Phillips, 1986; Schwertmann and Cornell, 2008). The precipitates were washed six times using 18.2 M $\Omega$ water, separating the precipitates by centrifuging at $17000 \mathrm{~g}$ for 20 minutes, and stored under $\mathrm{N}_{2}$ until required. The physical and chemical properties of these biomineralization products have extensively been characterized previously (Byrne et al., 2011).

A culture of G. sulfurreducens was prepared according to Lloyd et. al. 2003. Briefly, freshwater medium (Lovley and Phillips, 1988) was prepared, containing $20 \mathrm{mM}$ acetate as the electron donor and $40 \mathrm{mM}$ of 
fumarate as the electron acceptor, prepared under an $\mathrm{N}_{2}-\mathrm{CO}_{2}(80: 20)$ atmosphere, adjusted to a pH of 7 using $\mathrm{NaOH}$, determined using a Denver Instrument UB-10 bench top meter and a calibrated P Cole Parmer 5990-45 CCP probe. This medium was decanted in to serum bottles and sealed using a rubber bung and aluminum crimps, leaving a headspace of $\mathrm{N}_{2}-\mathrm{CO}_{2}(80: 20)$, prior to autoclaving for sterility. An inoculum of a growing culture of $G$. sulfurreducens was added at a $10 \% \mathrm{v} / \mathrm{v}$ ratio. For incubation with the $\mathrm{Fe}$ (III) starting phases, a late log phase culture of $G$. sulfurreducens was harvested by centrifugation (Sigma 6k15), at $4920 \mathrm{~g}$ for 20 minutes, and washed using a bicarbonate buffer under $\mathrm{N}_{2}-\mathrm{CO}_{2}(80: 20)$ gas. This concentrated cell suspension was used to inoculate sealed serum bottles containing $10 \mathrm{~g} \mathrm{~L}^{-1}$ of $\mathrm{Fe}$ (III) starting material (at $0.6 \mathrm{mg}$ protein $\mathrm{mL}^{-1}$ ), $20 \mathrm{mM} \mathrm{Na}$ acetate, $30 \mathrm{mM} \mathrm{NaHCO}_{3}$ and $10 \mu \mathrm{M}$ antraquinone-2,6-disulfonate (AQDS) under an atmosphere of $\mathrm{N}_{2}-\mathrm{CO}_{2}(80: 20)$ gas. These inoculated serum bottles were incubated at $30^{\circ} \mathrm{C}$ in the dark until transformation to magnetite was complete. Following incubation, the resulting magnetite was magnetically separated and washed using $18.2 \mathrm{M} \Omega$ water and stored at $4^{\circ} \mathrm{C}$ in the dark until use. The Fe concentration of the $\mathrm{BnM}$ slurry was determined by the acid extraction and ferrozine assay, as detailed in section 2.6.

\subsection{Functionalization of biogenic magnetite with $\operatorname{Pd}(0)$}

Biogenic magnetite was used to support surface-localized $\operatorname{Pd}(0)$, precipitated via the method detailed in (Coker et al., 2010). Briefly, under an $\mathrm{N}_{2}$ atmosphere an aliquot of the washed BnM slurry was added to a sterile serum bottle and crimp sealed using a rubber bung and aluminum crimps. An $\mathrm{N}_{2}$ degassed solution of $\mathrm{Na}_{2} \mathrm{PdCl}_{4}$ was prepared, at a concentration to give a final concentration of $\mathrm{Pd}$ on the magnetite as $2.4 \mathrm{wt} \% \mathrm{Pd}$. This solution was then added, using an $\mathrm{N}_{2}$ degassed syringe, to the $\mathrm{BnM}$ slurry while shaking prior to agitating on a roller shaker for 12 hours. In order to remove excess $\mathrm{Cl}^{-}$ions the resulting $\mathrm{Pd}-\mathrm{BnM}$ was washed under an $\mathrm{N}_{2}$ atmosphere, with 18.2 $\mathrm{M} \Omega$ water. The resulting slurry was sampled and solubilized using concentrated $\mathrm{HCl}$ and sent for ICP-AES analysis to confirm the concentration of $\mathrm{Fe}$ and $\mathrm{Pd}$, data not shown.

\subsection{Batch $\mathrm{ArNO}_{2}$ reduction experiments}

$\mathrm{ArNO}_{2}$ reduction by the $\mathrm{BnM}$ and the $\mathrm{Pd}-\mathrm{BnM}$ was tested using batch reaction experiments. These experiments were conducted in $50 \mathrm{~mL}$ serum bottles containing $30 \mathrm{~mL}$ of a $20 \mathrm{mM}$ MOPS buffer solution $(\mathrm{pH} 7.0)$ and a known concentration of $\mathrm{BnM}$ or $\mathrm{Pd}-\mathrm{BnM}$. The serum bottles were sealed using a rubber 
septum and aluminum crimps. The BnM experiment was flushed with pressurized $\mathrm{N}_{2}$ gas, while the PdBnM was flushed with pressurized $\mathrm{H}_{2}$, giving a pure $\mathrm{H}_{2}$ headspace within the bottles. The bottles were spiked with known concentrations of $\mathrm{ArNO}_{2} ; 150 \mu \mathrm{M}$ for the biogenic magnetite and 5 successive spikes of $1000 \mu \mathrm{M} \mathrm{ArNO}{ }_{2}$ for the Pd-BnM experiment. During batch BnM experiments, samples were removed after 1 minute followed by every 5 minutes up to 35 minutes after spiking with $\mathrm{ArNO}_{2}$. When spiked with Pd-BnM the experiment was sampled more regularly at intervals of $<5$ minutes, up to 104 minutes, after spiking with $\mathrm{ArNO}_{2}$. From both experiments, samples were removed by flushing a needle and syringe with pressurized $\mathrm{N}_{2}$ gas, passed through a $0.22 \mu \mathrm{m}$ filter. The samples were then $0.22 \mu \mathrm{m}$ filtered to remove the particle suspension and transferred immediately to a sealed high performance liquid chromatography (HPLC) vial for analysis by HPLC.

\subsection{Batch PCE dechlorination experiments}

The dechlorination of PCE by Pd-BnM was tested using batch headspace reaction experiments. These experiments were conducted using a buffered synthetic groundwater containing; $30 \mathrm{mg} \mathrm{L}^{-1} \mathrm{CaSO}_{4} \cdot 2 \mathrm{H}_{2} \mathrm{O}$, $30 \mathrm{mg} \mathrm{L}^{-1} \mathrm{MgSO}_{4}, 2 \mathrm{mg} \mathrm{L}^{-1} \mathrm{KCl}$ and $168 \mathrm{mg} \mathrm{L}^{-1} \mathrm{NaHCO}_{3} .10 \mathrm{~mL}$ sub-samples of this synthetic groundwater were placed in $20 \mathrm{~mL}$ glass serum bottles, leaving a 1:1 ratio of solution to headspace, and sealed using PTFE lined rubber septa and aluminum crimps. The following experimental treatments were prepared; $\mathrm{Pd}-\mathrm{BnM}+\mathrm{H}_{2}$ gas, $\mathrm{Pd}-\mathrm{BnM}$ control (no electron donor), $\mathrm{BnM}$ addition and $\mathrm{a} \mathrm{H}_{2}$ (no Pd$\mathrm{BnM}$ ) control. Bottles requiring electron donor for catalysis were degassed with pressurized $\mathrm{H}_{2}$ gas, giving a pure $\mathrm{H}_{2}$ headspace within the bottles. All other controls were degassed using pressurized $\mathrm{N}_{2}$ gas. A concentrated methanol stock solution of PCE was added to the test solutions to make a final concentration of $50 \mathrm{mg} \mathrm{L}^{-1}$, along with an internal standard $\left(2.5 \mathrm{mg} \mathrm{L}^{-1}\right.$ hexane). The final $\mathrm{pH}$ of this solution was 6.8 , maintaining this value over the duration of the experiment. The serum bottles were shaken vigorously by hand, and left on the roller shaker to allow the PCE to equilibrate between the liquid and gas phase. Prior to the addition of $\mathrm{Pd}-\mathrm{BnM}$, a headspace sample was taken for gas chromatography - flame ionization detector (GC-FID) analysis (see section 2.8). Addition of the Pd-BnM or $\mathrm{BnM}$ was carried out using an $\mathrm{N}_{2}$ degassed syringe to make a final concentration of $0.025 \mathrm{~g} \mathrm{Fe} \mathrm{L}^{-1}$ for the $\mathrm{Pd}-\mathrm{BnM}$, or $1 \mathrm{~g} \mathrm{Fe} \mathrm{L}^{-1}$ for the BnM control. All experiments were maintained at $20^{\circ} \mathrm{C} \pm 2^{\circ} \mathrm{C}$, on a roller shaker, in the dark. All control experiments were conducted in triplicate while the 2.4 wt $\% \mathrm{Pd}-\mathrm{BnM}+\mathrm{H}_{2}$ 
experiment was conducted 4 times. Each of these experiments was conducted with different individual timepoints, all of which are plotted in the results. Samples were removed at appropriate intervals, to give a good coverage over the experimental time span, while also aiming to minimize time between sampling and injection in to the GC. During sampling, the serum bottle was removed from the roller shaker and a headspace sample $(200 \mu \mathrm{L})$ removed. Samples were taken using a lockable gastight syringe (Hamilton SampleLock 1750 sl $0.5 \mathrm{~mL}$ syringe, Supelco Park, CA,USA), which had previously been degassed with was immediately injected in to the GC-FID for analysis.

\subsection{Analytical method - Fe(II) determination}

The Fe(II) concentration of the BnM was determined by the spectrophotometric ferrozine assay (Stookey, 1970). Initially the magnetite was extracted in hydrofluoric acid and the resulting extract then

$0.22 \mu \mathrm{m}$ filtered $\mathrm{N}_{2}$ gas, introducing $200 \mu \mathrm{L}$ of $\mathrm{N}_{2}$ in to the serum bottle so as to maintain atmospheric pressure inside the vessel, locking the syringe prior to removal. Once removed the headspace sample reacted with the ferrozine solution ( $1 \mathrm{~g} \mathrm{~L}^{-1}$ Ferrozine, $11.96 \mathrm{~g} \mathrm{~L}^{-1} \mathrm{HEPEs}$ buffer, adjusted to $\mathrm{pH}$ 7), according to (Lovley and Phillips, 1986). Analysis was performed on a Jenway 6715 UV/Vis spectrophotometer compared to calibration standards $\left(\mathrm{FeSO}_{4} \cdot 7 \mathrm{H}_{2} \mathrm{O}\right.$ solution).

\subsection{Analytical method $-\mathrm{ArNO}_{2}$}

$\mathrm{ArNO}_{2}$ batch experiment samples were analyzed by HPLC, performed on a Dionex GP50 gradient pump

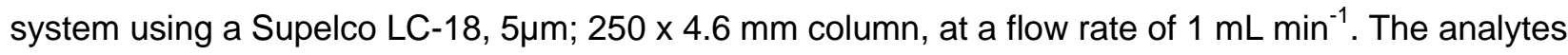
were detected using a Dionex UVD 170U 4-channel UV-vis detector by comparison to standards for $\mathrm{ArNO}_{2}$ and the product $\mathrm{ArNH}_{2}$.

\subsection{Analytical method - PCE}

Headspace samples of the PCE batch experiments were analyzed using GC-FID according to methods adapted from (Burris et al., 1996; Lowry and Reinhard, 1999); samples were injected at $50^{\circ} \mathrm{C}$ (held for 2 minutes) and the oven was programmed to $220^{\circ} \mathrm{C}$ at $40^{\circ} \mathrm{C} \mathrm{min}^{-1}$, at which it was held isothermal for 3 minutes. Helium $(\mathrm{He})$ was used as carrier gas at $30 \mathrm{~mL} \mathrm{~min}^{-1}$, identification was achieved by comparison to a PCE standard and quantification using an internal standard of $2.5 \mathrm{mg} \mathrm{L}^{-1}$ hexane (Sigma-Aldrich CHROMASOLV Plus, for HPLC, $\geq 95 \%$ ) added to the vial prior to analysis. Analysis was performed on an 
189 Agilent 7890A GC fitted with an Agilent J\&W GC HP-PLOT/Q column (30 m length and $0.535 \mathrm{~mm}$

190 diameter), equipped with on-column injector (set in splitless mode at $275^{\circ} \mathrm{C}$ ) and an FID (FID

191 temperature was $275^{\circ} \mathrm{C}$ ). The retention time of ethane was recorded from a gas standard. Its

192 concentration was estimated using Henry's Law, with (dimensionless) Henry's constants $\left(H_{c}\right)$ for PCE $\left(H_{c}\right.$

$193=0.60)$ calculated from (Gossett, 1987) and ethane $\left(H_{c}=20.4\right)$ (Mackay and Shiu, 1981), to determine

194 partitioning between the headspace and solution. This allowed an estimation of the ethane concentration

195 from the GC-FID carbon response.

\subsection{Evaluation of reaction kinetics - PCE}

To provide a comparison with previously reported kinetic data, for catalytic dechlorination of chlorinated hydrocarbons, the PCE dechlorination reaction was modeled using a simple pseudo- $1^{\text {st }}$ order rate law, as employed previously in (Lowry and Reinhard, 1999):

$$
-\frac{1}{C_{P d}} \frac{d C_{P C E}}{d t}=k_{o b s} C_{P C E}
$$

where $C_{P d}$ and $C_{P C E}$ represent the concentration of $\mathrm{Pd}$ and PCE respectively, the $k_{o b s}$ is the pseudo- $1^{\text {st }}$ order reaction rate constant calculated from the linear regression of $\ln [\mathrm{PCE}] \mathrm{vs} t$. The $k_{\text {obs }}$ are normalized by the concentration of $\mathrm{Pd}$ in the experiment to give $k_{P d}$ in $\mathrm{L} \mathrm{g}_{\mathrm{Pd}}{ }^{-1} \mathrm{~min}^{-1}$. Due to the presence of a pure $\mathrm{H}_{2}$ headspace and the saturation of the aqueous phase in respect to $\mathrm{H}_{2}$, it is assumed these are present in vast stoichiometric excess and do not impair reaction rates. For further comparison of the rate kinetics, the specific catalyst activity $\left(A_{P d}\right)$ as previously employed by (Hildebrand et al., 2009) was also calculated:

$$
A_{P d}=\frac{1}{C_{P d} t_{1} / 2}=\frac{\ln \left(C_{t 1} / C_{t 2}\right)}{\ln C_{P d}\left(t_{2}-t_{1}\right)}
$$


213 where $t_{1 / 2}$ represent the half life of the PCE during the reaction, $t_{1}$ and $t_{2}$ are two arbitrary sampling times,

$214 C_{t 1}$ and $C_{t 2}$ are their corresponding PCE concentrations.

\section{Results and discussion}

\section{1. $\mathrm{ArNO}_{2}$ reduction by biogenic magnetite}

218 Biogenic nano-magnetite (BnM) was synthesized from 2-line ferrihydrite powder using whole cells of $G$. 219 sulfurreducens within 2 days of inoculation. The reactivity of the BnM investigated here was assessed using $\mathrm{ArNO}_{2}$ as a chemical probe, with $\mathrm{BnM}$ added at the equivalent of $9.4 \mathrm{mM} \mathrm{Fe}(\mathrm{II})$. Both the disappearance of $\mathrm{ArNO}_{2}$ and the formation of the reduction product, $\mathrm{ArNH}_{2}$, were determined as a function of time (see Fig. 1), hypothesized to react via equations 1-3. The BnM rapidly reduced $\mathrm{ArNO}_{2}$, completely removing it over the initial 10 minutes of incubation. This was concurrent with the production of $\mathrm{ArNH}_{2}$ at a slower rate than $\mathrm{ArNO}_{2}$ was removed, evident from the sum of $\mathrm{ArNO}_{2}$ and $\mathrm{ArNH}_{2}$ concentrations (Fig. 1), which shows an initial decrease, possibly indicating reaction via nitroso- and hydroxylamino intermediates. Over the 35 minute time course the $150 \mu \mathrm{M} \mathrm{ArNO} \mathrm{N}_{2}$ was completely reduced to $\mathrm{ArNH}_{2}$. Taking in to account that to reduce $1 \mathrm{M} \mathrm{ArNO}_{2}$ it would require the oxidation of $6 \mathrm{M}$ $\mathrm{Fe}(\mathrm{II})$, the starting concentration of $\mathrm{Fe}(\mathrm{II})$ used here is in 21 times stoichiometric excess to the $\mathrm{ArNO}_{2}$. Although this assumes the availability of all the structural Fe(II) in the magnetite, it easily accounts for 230 the complete removal of the $\mathrm{ArNO}_{2}$.

\section{2. $\mathrm{ArNO}_{2}$ Reduction by $\mathrm{Pd}(0)$ functionalized biogenic magnetite}

233 The intrinsic limitation of the availability of electrons at the mineral-solution interface in the magnetite 234 system makes its application to the reduction of contaminants, in the absence of a method to replenish $235 \mathrm{Fe}(\mathrm{II})$, limited. To address this, the surface of the magnetite was functionalized with $\mathrm{Pd}(0)$ and again 236 tested for prolonged $\mathrm{ArNO}_{2}$ reduction with $\mathrm{H}_{2}$ gas supplied as the electron donor.

237 The sustained reactivity of the Pd-BnM is evidenced by the maintenance of the reductive capacity 238 following repeated spiking with $1000 \mu \mathrm{M} \mathrm{ArNO}$ (Fig. 2). In total $5000 \mu \mathrm{M} \mathrm{ArNO}$, was removed without 239 loss of activity, equivalent to the stoichiometric generation of $30 \mathrm{mM}$ of electron reduction equivalents. 
240 This represents a far greater removal than is potentially possible by the Fe(II)-mediated BnM systems 241 (without the Pd coating), due to the replenishment of catalytic reactivity in the presence of the electron 242 donor $\mathrm{H}_{2}$. The hydrogenation of $\mathrm{ArNO}_{2}$, by a $\mathrm{Pd}(0)$ catalyst, has been described previously by several 243 authors (Gelder et al., 2002; Sangeetha et al., 2009), and is the typical method employed for the 244 production of $\mathrm{ArNH}_{2}$ in industrial processes (Wisniak and Klein, 1984).The sustained reactivity presented here, under ambient conditions, would indicate that the employment of $\mathrm{Pd}(0)$ supported on $\mathrm{BnM}$ is an efficient reduction mechanism for the treatment of $\mathrm{ArNO}_{2}$.

\subsection{PCE reduction}

In addition to the hydrogenation of $\mathrm{ArNO}_{2}$, the $\mathrm{BnM}$ and the $\mathrm{Pd}-\mathrm{BnM}$ were used to treat the more recalcitrant PCE. Dechlorination of PCE by magnetite has been observed previously (Lee and Batchelor, 2002), however, this was found to proceed slowly over 100 days of reaction. In these experiments, a buffer reflective of realistic groundwater composition was used to give a closer approximation to contaminated land and water scenarios. In line with this, even in a great stoichiometric excess of magnetite $\left(1 \mathrm{~g} \mathrm{Fe} \mathrm{L}^{-1}\right)$, little dechlorination over the short timescale of this experiment was noted (Fig. 3(a)). By contrast, upon functionalization with $\mathrm{Pd}(0)$, dechlorination proceeded rapidly to the hydrogenated end product ethane (Fig. 3(a)). It should be noted that a minor decrease in the mass balance (PCE + ethane) is noted within the first 5 minutes of the reaction, indicating the presence of degradation intermediates, described in equations 4-7. However, with minimal detection of partially chlorinated products or the unsaturated hydrocarbon, ethylene, it is unclear what is responsible for this loss in mass. This mass loss is not likely the result of adsorption, where for $\mathrm{Pd}-\mathrm{BnM}$ in the absence of $\mathrm{H}_{2}$ (Supporting information Fig. S1), no PCE removal occurred. The good overall selectivity towards nontoxic ethane production is desirable, where no evidence for significant by-product accumulation was noted, and wholly consistent with previous studies employing a variety of $\mathrm{Pd}(0)$ catalysts; $\mathrm{Pd}(0)-\mathrm{Al}_{2} \mathrm{O}_{3}$ (Lowry and Reinhard, 1999), Pd(0)-Au (Nutt et al., 2006; Nutt et al., 2005) and unsupported Pd(0) (Heck et al., 2009). In addition, no PCE removal was observed in the presence of $\mathrm{H}_{2}$ but the absence of the Pd$\mathrm{BnM}$ (Supporting information Fig. S1), evidence that the catalytic $\operatorname{Pd}(0)$ is required for dehalogenation of the PCE. 
268 The $k_{P d}$ and the $A_{P d}$ values, calculated from the linear regression of $\ln [\mathrm{PCE}]$ (Fig. 4), of $334 \pm 18$ and $492 \pm 25 \mathrm{~L} \mathrm{~g} \mathrm{gd}^{-1} \mathrm{~min}^{-1}$ respectively (Table 1), allow direct comparison of dechlorination rates to literature values. A review by (Chaplin et al., 2012) presented a compilation of the reaction rate constants observed for dechlorination of all chlorinated alkenes by $\mathrm{Pd}(0)$ showing rates in the order of 10 s to 10000 $\mathrm{L} \mathrm{gPd}^{-1} \mathrm{~min}^{-1}$ for a wide range of substrates including PCE. The values presented here fall within this range of values; the wide range of reported values is probably due to the wide variety of experimental conditions employed (and the wide spectrum of substrates), therefore, it is worth comparing directly with similar studies focusing on PCE. Specifically the PCE dechlorination $k_{\text {catalyst }}$ noted using a $\mathrm{Pd}(0)-\mathrm{Al}_{2} \mathrm{O}_{3}$ catalyst, have been reported to be in the order of $53 \mathrm{~L} \mathrm{~g}_{\mathrm{Pd}}{ }^{-1} \mathrm{~min}^{-1}$, normalized to $\mathrm{Pd}$ content, where $\mathrm{Pd}(0)$ scale $\mathrm{Pd}(0)$ on $\mathrm{Al}_{2} \mathrm{O}_{3}$. observed in this study, possibly due to the nano-scale of the Pd-BnM employed, compared to the micron

Fewer studies have been carried out on the fully chlorinated PCE, compared to the less (tri) chlorinated TCE, however, as the fully chlorinated compound (PCE) dechlorinates via TCE, it was chosen so as to be relevant to a wider scope of chlorinated compounds. Despite PCE being reported as a more readily reduced than TCE (Elsner and Hofstetter, 2011), a previous study has shown that the TCE is dechlorinated slightly faster than PCE by $\operatorname{Pd}(0)$ catalysts (Lowry and Reinhard, 1999). An extremely active catalyst was identified for the dechlorination of TCE, in the form of $\operatorname{Pd}(0)-A u$, recording a $k_{P d}$ dependent upon $\operatorname{Pd}(0) \%$, ranging from $173-943 \mathrm{~L} \mathrm{~g}_{\mathrm{Pd}}{ }^{-1} \mathrm{~min}^{-1}$, for 33 and $1.9 \mathrm{wt} \% \operatorname{Pd}(0)$ respectively (Nutt et al., 2005). This study also found conventional unsupported $\operatorname{Pd}(0)$ to have a $k_{P d}$ of $62 \mathrm{~L} \mathrm{~g}_{P d}{ }^{-1} \mathrm{~min}^{-1}$ and a $\mathrm{Pd}(0)-\mathrm{Al}_{2} \mathrm{O}_{3}$ catalyst to have a $k_{P d}$ of $12 \mathrm{~L} \mathrm{~g}_{P d}{ }^{-1} \mathrm{~min}^{-1}$. In a later study, also with a $\mathrm{Pd}(0)-A u$ catalyst, a higher $k_{P d}$ of $1956 \mathrm{~L} \mathrm{~g}_{P_{d}}{ }^{-1} \min ^{-1}$ was achieved for a Pd loading of $12.7 \mathrm{wt} \%$ upon Au, equivalent to between 50 and 75\% surface Pd coverage of the $4 \mathrm{~nm}$ Au particle (Nutt et al., 2006). The high reactivity of the $\operatorname{Pd}(0)-A u$ catalyst was inferred to be a result of the promoting effect of Au due to electronic or geometric controls.

The specific catalyst activity $\left(A_{P d}\right)$ value presented here (Table 1$)$ is below that reported previously for an unsupported $\mathrm{Pd}(0)$ nanoparticle and a Pd-on-Au catalyst; exhibiting $A_{P d}$ values of $2100 \pm 300 \mathrm{~L} \mathrm{~g}_{\mathrm{Pd}}{ }^{-1} \mathrm{~min}^{-}$

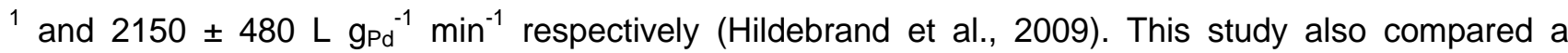


synthetic magnetite supported $\mathrm{Pd}(0)$ heterostructure towards TCE dechlorination with varying wt \% $\mathrm{Pd}$. For wt \% Pd(0) values similar to those used by (Hildebrand et al., 2009) of 5 wt \% loading on magnetite, a $A_{P d}$ of $520 \pm 180 \mathrm{~L} \mathrm{~g}_{\mathrm{Pd}}{ }^{-1} \mathrm{~min}^{-1}$ was obtained, comparable to the value presented here for 2.4 wt $\% \operatorname{Pd}(0)$ (492 $\pm 25 \mathrm{~L} \mathrm{~g} \mathrm{gd}^{-1} \mathrm{~min}^{-1}$ ) loading towards PCE. An inverse relationship with Pd content and specific reaction rate was noted, with the highest rate of $6100 \pm 180 \mathrm{~L} \mathrm{gPd}^{-1} \mathrm{~min}^{-1}$ observed at a Pd loading of 0.15 wt \% Pd on magnetite. This greater reactivity of the lower $\mathrm{Pd}(0)$ loading in (Hildebrand et al., 2009) was hypothesized to be a result of increased dispersion of smaller $\operatorname{Pd}(0)$ particles increasing exposed surface $\operatorname{Pd}(0)$ atoms for reaction. The high reactivity of the synthetic $\operatorname{Pd}(0)$ on magnetite and the biogenic magnetites presented here would seem to provide a highly reactive alternative to the costly promoter metal $\mathrm{Au}$, with the dual advantage of providing a magnetically recoverable support.

\section{Table 1. Calculated psuedo-1st order reaction rate constants and specific catalyst activity for dechlorination of PCE by Pd-BnM}

\begin{tabular}{|c|c|c|c|c|c|}
\hline Catalyst & $P d g^{-1}$ & $\begin{array}{c}K_{o b s} \\
\left(\min ^{-1}\right)\end{array}$ & $R^{2}$ & $\begin{array}{c}K_{P d}{ }^{a} \\
\left(\operatorname{Lg}_{P d}^{-1} \min ^{-1}\right)\end{array}$ & $\begin{array}{c}A_{P d}^{b} \\
\left(\operatorname{L~g~}_{P d}^{-1} \min ^{-1}\right)\end{array}$ \\
\hline d-BnM & $7.94 \times 10^{-4}$ & $0.265 \pm 0.014$ & 0.97 & $334 \pm 18$ & $492 \pm 25$ \\
\hline
\end{tabular}

a 1 st order rate constant normalized to $\mathrm{g}^{-1} \mathrm{Pd}$ (see section 2.9)

${ }^{\mathrm{b}}$ specific catalyst activity (see section 2.9 )

\subsection{Implications for bio-nanoremediation}

There is a growing realization that the metabolic processes of microorganisms can be harnessed for the production of functional nanomaterials, with a wide variety of applications, including contaminant remediation (Hennebel et al., 2009; Lloyd et al., 2010). These materials are proving to have comparable or better functional properties than synthetic alternatives (Coker et al., 2010), leading to several studies focusing on their reactivity towards contaminant remediation (De Corte et al., 2012; Mabbett and Macaskie, 2002; Watts et al., 2015). The present study supports the growing realization of the comparable reactivity of biogenic nanoparticles to synthetic alternatives. It also demonstrates the improvements gained through functionalization of nanoparticles, a process which can be achieved 
318 through a one-step reaction with BnM (Coker et al., 2010). The possibilities of modifying the biogenic

319 particles is also a key focus (Byrne et al., 2011; De Windt et al., 2006; Redwood et al., 2008; Sobjerg et

320 al., 2011) and its impact on reactivity remains to be fully explored. The challenges of applying this

321 technology at field scale also need to be addressed, with work being done to scale up their bioproduction

322 (Byrne et al., 2015), and development of novel in situ deployment technologies (Chidambaram et al., 323 2010).

\section{Conclusions}

326 In summary both the un-functionalized $\mathrm{BnM}$ and the $\mathrm{Pd}-\mathrm{BnM}$ catalyst (the latter supplied with $\mathrm{H}_{2}$ ), 327 exhibited high reactivity towards $\mathrm{ArNO}_{2}$ in batch systems. Both were able to fully transform $\mathrm{ArNO} \mathrm{N}_{2}$ to the 328 reduced product $\mathrm{ArNH}_{2}$, mediated by $\mathrm{Fe}(\mathrm{II})$ in the magnetite, and reducing power replenished in the $\mathrm{Pd}$ $329 \mathrm{BnM}$ treatment by the $\mathrm{H}_{2}$ electron donor. Indeed, the Pd-BnM was able to efficiently reduce high 330 quantities of $\mathrm{ArNO}_{2}, 5000 \mu \mathrm{M}$ in total, without showing any loss in reactivity. Moving towards treatment of 331 the more recalcitrant organic contaminant, PCE, the BnM was un-reactive on the short timescales of the experiment employed here. In contrast, the Pd-BnM was highly reactive, resulting in the fast degradation 333 to the benign product ethane. The modeled reaction rates are extremely fast and are comparable to 334 those previously reported in the literature for $5 \% \operatorname{Pd}(0)$ on synthetic magnetite towards reaction with 335 TCE. The Pd-BnM employed here, therefore represents a more reactive nanoparticle treatment than the $336 \mathrm{Fe}(\mathrm{II})$ based BnM alone and is better suited to treatment of more recalcitrant contaminants. However, the 337 BnM still exhibited good reactivity towards the less recalcitrant test compound $\mathrm{ArNO}_{2}$. Biotechnological 338 routes for $\mathrm{BnM}$ and $\mathrm{Pd}-\mathrm{BnM}$ offer scalable, environmentally benign alternatives to the synthetic 339 production processes currently available for highly reactive nanoparticles, resulting in the tunable 340 synthesis of bionanoparticles that are well suited to the treatment of a wide range of organic and 341 inorganic contaminants. Current research focuses on their synthesis from waste materials and 342 subsequent deployment in a range of contaminated land scenarios. 
MPW acknowledges financial support from the BBSRC for PhD bursary and CASE partner Parsons

Brinckerhoff. The research leading to these results has also received funding from the European Union

Seventh Framework Programme (FP7 / 2007-2013) under Grant Agreement No. 309517 (NANOREM).

\section{References}

Albright, R., 2011. Cleanup of chemical and explosive munitions: Location, identification and environmental remediation, 2nd ed. Elsevier, New York, USA.

Burris, D.R., Delcomyn, C.A., Smith, M.H., Roberts, A.L., 1996. Reductive dechlorination of tetrachloroethylene and trichloroethylene catalyzed by vitamin B12 in homogeneous and heterogeneous systems. Environ. Sci. Technol. 30, 3047-3052.

Byrne, J., Muhamadali, H., Coker, V., Cooper, J., Lloyd, J., 2015. Scale-up of the production of highly reactive biogenic magnetite nanoparticles using Geobacter sulfurreducens. Journal of The Royal Society Interface 12 , 20150240.

Byrne, J.M., Telling, N.D., Coker, V.S., Pattrick, R.A.D., Laan, G.v.d., Arenholz, E., Tuna, F., Lloyd, J.R., 2011. Control of nanoparticle size, reactivity and magnetic properties during the bioproduction of magnetite by Geobacter sulfurreducens. Nanotechnology 22, 455709.

Chaplin, B.P., Reinhard, M., Schneider, W.F., Schüth, C., Shapley, J.R., Strathmann, T.J., Werth, C.J., 2012. Critical review of Pd-based catalytic treatment of priority contaminants in water. Environ. Sci. Technol. 46, 3655-3670.

Chidambaram, D., Hennebel, T., Taghavi, S., Mast, J., Boon, N., Verstraete, W., van der Lelie, D., Fitts, J.P., 2010. Concomitant microbial generation of palladium nanoparticles and hydrogen to immobilize chromate. Environ. Sci. Technol. 44, 7635-7640.

Coker, V.S., Bennett, J.A., Telling, N.D., Henkel, T., Charnock, J.M., van der Laan, G., Pattrick, R.A.D., Pearce, C.I., Cutting, R.S., Shannon, I.J., Wood, J., Arenholz, E., Lyon, I.C., Lloyd, J.R., 2010. Microbial engineering of nanoheterostructures: biological synthesis of a magnetically recoverable palladium nanocatalyst. ACS Nano 4, 2577-2584.

Coker, V.S., Garrity, A., Wennekes, W.B., Roesink, H.D.W., Cutting, R.S., Lloyd, J.R., 2014. Cr(VI) and azo dye removal using a hollow-fibre membrane system functionalized with a biogenic Pd-magnetite catalyst. Environ. Technol. 8, 1046-1054.

Conrad, H., Ertl, G., Latta, E.E., 1974. Adsorption of hydrogen on palladium single crystal surfaces. Surface Science 41, 435-446.

Cornell, R.M., Schwertmann, U., 2003. The Iron oxides : structure, properties, reactions, occurences and uses (2nd ed.). Wiley-VCH, Weinheim.

Crean, D.E., Coker, V.S., van der Laan, G., Lloyd, J.R., 2012. Engineering biogenic magnetite for sustained $\mathrm{Cr}(\mathrm{VI})$ remediation in flow-through systems. Environ. Sci. Technol. 46, 3352-3359.

Cutting, R.S., Coker, V.S., Fellowes, J.W., Lloyd, J.R., Vaughan, D.J., 2009. Mineralogical and morphological constraints on the reduction of Fe(III) minerals by Geobacter sulfurreducens. Geochim. Cosmochim. Acta 73, 4004-4022.

Cutting, R.S., Coker, V.S., Telling, N.D., Kimber, R.L., Pearce, C.I., Ellis, B.L., Lawson, R.S., van der Laan, G., Pattrick, R.A.D., Vaughan, D.J., Arenholz, E., Lloyd, J.R., 2010. Optimizing Cr(VI) and Tc(VII) remediation through nanoscale biomineral engineering. Environ. Sci. Technol. 44, 2577-2584.

Danielsen, K.M., Hayes, K.F., 2004. pH dependence of carbon tetrachloride reductive dechlorination by magnetite. Environ. Sci. Technol. 38, 4745-4752.

Davie, M.G., Cheng, H., Hopkins, G.D., LeBron, C.A., Reinhard, M., 2008. Implementing heterogeneous catalytic dechlorination technology for remediating TCE-contaminated groundwater. Environ. Sci. Technol. 42 , 8908-8915.

De Corte, S., Sabbe, T., Hennebel, T., Vanhaecke, L., De Gusseme, B., Verstraete, W., Boon, N., 2012. Doping of biogenic Pd catalysts with Au enables dechlorination of diclofenac at environmental conditions. Water Res. 46, 2718-2726.

De Windt, W., Boon, N., Van den Bulcke, J., Rubberecht, L., Prata, F., Mast, J., Hennebel, T., Verstraete, W., 2006. Biological control of the size and reactivity of catalytic $\mathrm{Pd}(0)$ produced by; Shewanella oneidensis. Antonie Van Leeuwenhoek 90, 377-389.

Elsner, M., Hofstetter, T., 2011. Current perspectives on the mechanisms of chlorohydrocarbon degradation in subsurface environments: Insight from kinetics, product formation, probe molecules and isotope fractionation. Aquatic Redox Chemistry 1071, 407-439. 
Elsner, M., Schwarzenbach, R.P., Haderlein, S.B., 2004. Reactivity of Fe(II)-bearing minerals toward reductive transformation of organic contaminants. Environ. Sci. Technol. 38, 799-807.

Gelder, E.A., Jackson, S.D., Lok, C.M., 2002. A study of nitrobenzene hydrogenation over palladium/carbon catalysts. Catalysis Letters 84, 205-208.

Gorski, C.A., Nurmi, J.T., Tratnyek, P.G., Hofstetter, T.B., Scherer, M.M., 2010. Redox behavior of magnetite: Implications for contaminant reduction. Environ. Sci. Technol. 44, 55-60.

Gorski, C.A., Scherer, M.M., 2009. Influence of magnetite stoichiometry on Fell uptake and ntrobenzene reduction. Environ. Sci. Technol. 43, 3675-3680.

Gossett, J.M., 1987. Measurement of Henry's law constants for C1 and C2 chlorinated hydrocarbons. Environ. Sci. Technol. 21, 202-208.

Gregory, K.B., Larese-Casanova, P., Parkin, G.F., Scherer, M.M., 2004. Abiotic transformation of hexahydro1,3,5-trinitro-1,3,5-triazine by Fell bound to magnetite. Environ. Sci. Technol. 38, 1408-1414.

Gu, B., Phelps, T., Liang, L., Dickey, M., Roh, Y., Kinsall, B., Palumbo, A., Jacobs, G., 1999. Biogeochemical dynamics in zero-valent iron columns: Implications for permeable reactive barriers. Environ. Sci. Technol. 33, 2170-2177.

Heck, K.N., Nutt, M.O., Alvarez, P., Wong, M.S., 2009. Deactivation resistance of Pd/Au nanoparticle catalysts for water-phase hydrodechlorination. Journal of Catalysis 267, 97-104.

Hennebel, T., De Gusseme, B., Boon, N., Verstraete, W., 2009. Biogenic metals in advanced water treatment. Trends Biotechnol. 27, 90-98.

Henry, C.R., 1998. Surface studies of supported model catalysts. Surface Science Reports 31, $231-325$.

Hildebrand, H., Mackenzie, K., Kopinke, F.-D., 2009. Highly active Pd-on-magnetite nanocatalysts for aqueous phase hydrodechlorination reactions. Environ. Sci. Technol. 43, 3254-3259.

Kappler, A., Straub, K.L., 2005. Geomicrobiological cycling of iron. Reviews in Mineralogy and Geochemistry 59, 85-108.

Klausen, J., Troeber, S.P., Haderlein, S.B., Schwarzenbach, R.P., 1995. Reduction of substituted nitrobenzenes by $\mathrm{Fe}(\mathrm{II})$ in aqueous mineral suspensions. Environ. Sci. Technol. 29, 2396-2404. Latta, D.E., Gorski, C.A., Boyanov, M.I., O'Loughlin, E.J., Kemner, K.M., Scherer, M.M., 2012. Influence of magnetite stoichiometry on UVI reduction. Environ. Sci. Technol. 46, 778-786.

Lee, W., Batchelor, B., 2002. Abiotic reductive dechlorination of chlorinated ethylenes by iron-bearing soil minerals. 1. pyrite and magnetite. Environ. Sci. Technol. 36, 5147-5154.

Lloyd, J.R., Byrne, J.M., Coker, V.S., 2010. Biotechnological synthesis of functional nanomaterials. Curr. Opin. Biotechnol. 22, 509-515.

Lloyd, J.R., Sole, V.A., Van Praagh, C.V.G., Lovley, D.R., 2000. Direct and Fe(II)-mediated reduction of technetium by Fe(III)-reducing bacteria. Appl. Environ. Microbiol. 66, 3743-3749.

Lovley, D.R., Phillips, E.J.P., 1986. Availability of ferric iron for microbial reduction in bottom sediments of the freshwater tidal potomac river. Appl. Environ. Microbiol. 52, 751-757.

Lovley, D.R., Phillips, E.J.P., 1988. Novel mode of microbial energy metabolism: Organic carbon oxidation coupled to dissimilatory reduction of iron or manganese. Appl. Environ. Microbiol. 54, 1472-1480.

Lovley, D.R., Stolz, J.F., Nord, G.L., Phillips, E.J.P., 1987. Anaerobic production of magnetite by a dissimilatory iron-reducing microorganism. Nature 330, 252-254.

Lowry, G.V., Reinhard, M., 1999. Hydrodehalogenation of 1- to 3-carbon halogenated organic compounds in water using a palladium catalyst and hydrogen gas. Environ. Sci. Technol. 33, 1905-1910.

Mabbett, A.N., Macaskie, L.E., 2002. A new bioinorganic process for the remediation of $\mathrm{Cr}(\mathrm{VI})$. Journal of Chemical Technology \& Biotechnology 77, 1169-1175.

Mackay, D., Shiu, W.Y., 1981. A critical review of Henry's law constants for chemicals of environmental interest. Journal of Physical and Chemical Reference Data 10, 1175-1199.

McBeth, J.M., Lloyd, J.R., Law, G.T.W., Livens, F.R., Burke, I.T., Morris, K., 2011. Redox interactions of technetium with iron-bearing minerals. Mineralogical Magazine 75, 2419-2430.

McNab, W.W., Ruiz, R., Reinhard, M., 2000. In-situ destruction of chlorinated hydrocarbons in groundwater using catalytic reductive dehalogenation in a reactive well: testing and operational experiences. Environ. Sci. Technol. 34, 149-153.

Missana, T., García-Gutiérrez, M., Fernńdez, V., 2003. Uranium (VI) sorption on colloidal magnetite under anoxic environment: experimental study and surface complexation modelling. Geochim. Cosmochim. Acta 67, 2543-2550.

Nutt, M.O., Heck, K.N., Alvarez, P., Wong, M.S., 2006. Improved Pd-on-Au bimetallic nanoparticle catalysts for aqueous-phase trichloroethene hydrodechlorination. Applied Catalysis B: Environmental 69, $115-125$. Nutt, M.O., Hughes, J.B., Wong, M.S., 2005. Designing Pd-on-Au bimetallic nanoparticle catalysts for trichloroethene hydrodechlorination. Environ. Sci. Technol. 39, 1346-1353.

Olowe, A.A., Rezel, D., Génin, J.M.R., 1989. Mechanism of formation of magnetite from ferrous hydroxide in aqueous corrosion processes. Hyperfine Interactions 46, 429-436. 
Redwood, M.D., Deplanche, K., Baxter-Plant, V.S., Macaskie, L.E., 2008. Biomass-supported palladium catalysts on Desulfovibrio desulfuricans and Rhodobacter sphaeroides. Biotechnol. Bioeng. 99, 1045-1054. Sangeetha, P., Shanthi, K., Rao, K.S.R., Viswanathan, B., Selvam, P., 2009. Hydrogenation of nitrobenzene over palladium-supported catalysts - Effect of support. Applied Catalysis A: General 353, 160-165.

Scherer, M.M., Johnson, K.M., Westall, J.C., Tratnyek, P.G., 2001. Mass transport effects on the kinetics of nitrobenzene reduction by iron metal. Environ. Sci. Technol. 35, 2804-2811.

Schwertmann, U., Cornell, R.M., 2008. Iron oxides in the laboratory. Wiley-VCH Verlag GmbH, Weinheim, Germany.

Sobjerg, L.S., Lindhardt, A.T., Skrydstrup, T., Finster, K., Meyer, R.L., 2011. Size control and catalytic activity of bio-supported palladium nanoparticles. Colloids Surf. B. Biointerfaces 85, 373-378.

Stookey, L.L., 1970. Ferrozine-a new spectrophotometric reagent for iron. Analytical Chemistry 42, 779-781. Tierney, H.L., Baber, A.E., Kitchin, J.R., Sykes, E.C.H., 2009. Hydrogen dissociation and spillover on individual isolated palladium atoms. Physical Review Letters 103, 246102.

Watts, M.P., Coker, V.S., Parry, S.A., Thomas, R.A.P., Kalin, R., Lloyd, J.R., 2015. Effective treatment of alkaline $\mathrm{Cr}(\mathrm{VI})$ contaminated leachate using a novel Pd-bionanocatalyst: Impact of electron donor and aqueous geochemistry. Applied Catalysis B: Environmental 170-171, 162-172.

Wiatrowski, H.A., Das, S., Kukkadapu, R., Ilton, E.S., Barkay, T., Yee, N., 2009. Reduction of Hg(II) to Hg(0) by magnetite. Environ. Sci. Technol. 43, 5307-5313.

Wisniak, J., Klein, M., 1984. Reduction of nitrobenzene to aniline. Industrial \& Engineering Chemistry Product Research and Development 23, 44-50.

Yamauchi, M., Ikeda, R., Kitagawa, H., Takata, M., 2008. Nanosize effects on hydrogen storage in palladium. The Journal of Physical Chemistry C 112, 3294-3299. 